\section{State of the Art and Future Perspectives}

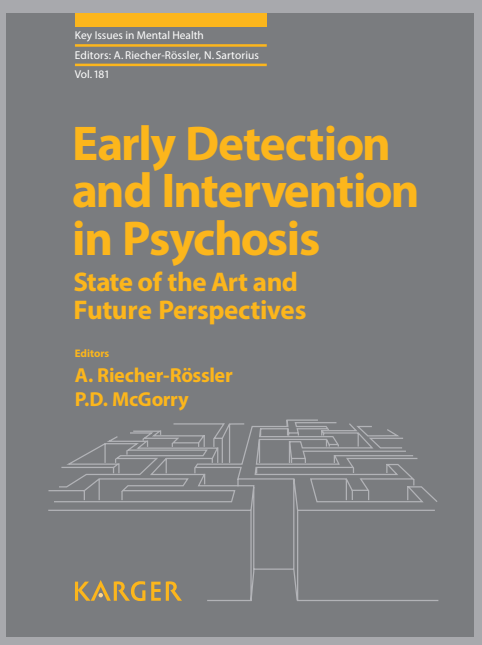

This new volume reviews early detection approaches and possible subsequent interventions for psychosis. After introductory chapters, various methods for early detection not only in adults, but also adolescents are described. In this context, the validity of the psychosis high-risk state is debated along with whether early detection is indeed helpful, or actually stigmatizing, for the patient. Further contributions review neuroimaging, including structural and functional MRI, as well as pattern recognition methods and measurement of connectivity abnormalities. Neurocognitive and neurophysiological assessments are also discussed in detail. The last part focuses on early intervention for emerging psychosis, including psychological methods, non-pharmacological substances and pharmacological treatments. Overall conclusions and future perspectives are provided in a final chapter.

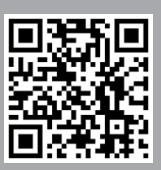

www.karger.com/kismh
Key Issues in Mental Health, Vol. 181

State of the Art and Future Perspectives Editors: Riecher-Rössler, A. (Basel); McGorry, P. (Parkville, Vic.)

XIV + 194 p., 16 fig., 10 in color, 11 tab., 2016 CHF 98.00 / EUR 92.00 / USD 115.00 (hard cover) CHF 118.00 / EUR 110.00 / USD 138.00 (online) Online version for institutional purchase Prices subject to change, VAT not included EUR price for eurozone countries, USD price for USA and Latin America only ISBN 978-3-318-05620-4 (hard cover) e-ISBN 978-3-318-05621-1

\section{CONTENTS}

Foreword:

Carpenter, W.T.

Preface and Introduction:

Riecher-Rössler, A.; McGorry, P.D.

Early Detection of Psychosis - State of the Art and Future Perspectives:

Klosterkötter, J.

Early Intervention in Emerging Psychosis: State of the Art and Future Perspectives: McGorry, P.D.; Goldstone, S.

First Signs of Emerging Psychosis: Schultze-Lutter, F.

Psychosis High-Risk States in Adolescents: Simon, A.E.

The Psychosis High-Risk State: Rutigliano, G.; Manalo, M.; Fusar-Poli, P.

Early Detection of Psychosis - Helpful or Stigmatizing Experience for Those Concerned?: Uttinger, M.; Papmeyer, M.; Riecher-Rössler, A.

Structural and Functional MRI in the Prediction of Psychosis: Dwyer, D.B.; McGuire, P.

Pattern Recognition Methods in the Prediction of Psychosis: Koutsouleris, N.; Kambeitz, J.

Connectivity Abnormalities in Emerging Psychosis:

Schmidt, A.; Borgwardt, S.

Neurocognition and Motor Functioning in the Prediction of Psychosis:

Studerus, E.; Papmeyer, M.; Riecher-Rössler, A.

Electroencephalographic Predictors of Psychosis:

Ruhrmann, S.

Psychological Methods of Early Intervention in Emerging Psychosis: Müller, H.; Bechdolf, A.

Nonpharmalogical Substances for Early Intervention:

Conus, P.

Pharmacological Intervention in First-Episode Psychosis: O'Donoghue, B.; Walter, M.; Huber, C.G.; Lang, U.E.

Early Detection and Intervention in Psychosis: Riecher-Rössler, A.; McGorry, P.D.

Fields of Interest: Psychiatry; Psychology; Psychotherapy; Pharmacology; Neurology 


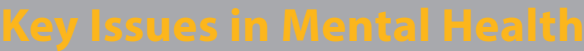

Series Editors:

Riecher-Rössler, A. (Basel); Sartorius, N. (Geneva)

ISSN 1662-4874, e-ISSN 1662-4882

With its first volume published in 1917, this series has served to chart some of the main developments of contemporary psychiatry. Throughout these years, individual volumes have outlined the specific problems and controversies which have characterized the growth of psychiatry and have reflected a broadening acceptance of its methods and applications. Recent volumes have been distinguished by their bench to bedside coverage of current topics in psychiatry, psychology and neurosciences. Taking a rigorously interdisciplinary as well as translational approach, Key Issues in Mental Health attempts to build bridges to related disciplines in an effort to integrate a variety of aspects relevant to the successful diagnosis and treatment of psychiatric disorders.

Indexing / Abstracting

'Key Issues in Mental Health' volumes are listed in bibliographic services including Thomson Reuters indices.

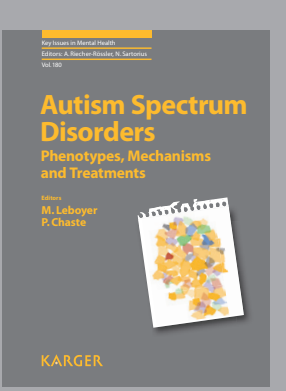

Vol. 180

Phenotypes, Mechanisms and Treatments

Editors: Leboyer, M. (Créteil);

Chaste, P. (Pittsburgh, Pa.)

$\mathrm{VI}+170$ p., 5 fig., 4 in color, 6 tab., 2015

CHF 93.00 / EUR 87.00 / USD 109.00 (hard cover)

CHF 112.00 / EUR 104.00 / USD 131.00 (online)

ISBN 978-3-318-02601-6 (hard cover)

e-ISBN 978-3-318-02602-3

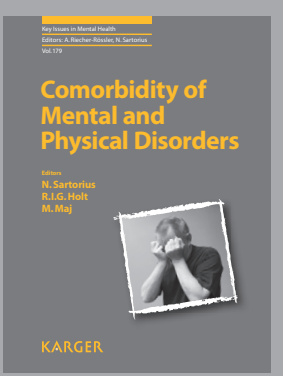

Vol. 179

Editors: Sartorius, N. (Geneva);

Holt, R.I.G. (Southampton)

Maj M. (Naples)

XII + 188 p., 12 fig., 20 tab., 2015

CHF 89.00 / EUR 83.00 / USD 105.00 (hard cover)

CHF 107.00 / EUR 100.00 / USD 126.00 (online)

ISBN 978-3-318-02603-0 (hard cover)

e-ISBN 978-3-318-02604-7

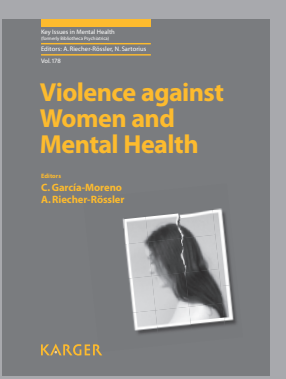

Vol. 178

Editors: García-Moreno, C. (Geneva);

Riecher-Rössler, A. (Basel)

XII + 180 p., 5 fig., 9 tab., 2013

CHF 79.00 / EUR 74.00 / USD 93.00 (hard cover)

CHF 95.00 / EUR 89.00 / USD 112.00 (online)

ISBN 978-3-8055-9988-7 (hard cover)

e-ISBN 978-3-8055-9989-4

Vol. 1-177 available,

please ask for details.

Online version for institutional purchase

Prices subject to change, VAT not included

EUR price for Eurozone countries,

USD price for USA and Latin America only

www.karger.com/kismh

\section{ORDER FORM}

Please send:

copy/ies: Vol. 181:

CHF 98.00 / EUR 92.00 / USD 115.00

ISBN 978-3-318-05620-4

copy/ies:

ISBN 978-3-318-

information on Vol. 180:

information on Vol. 179:

information on Vol. 178:

the book series

on continuation beginning with vol.

All Karger series are available on continuation. Each volume will be sent upon publication until order is countermanded.

For easy ordering or further information about the series log on to: www.karger.com/kismh

Postage and handling free with prepayment

Please charge this order to my credit card

$\begin{array}{ll}\text { American Express } & \text { Diners } \\ \text { Visa } & \text { Mastercard }\end{array}$

Card No.:

Exp. date:

CVV/CVC:

Check enclosed

Please bill me

Name/Address (please print):

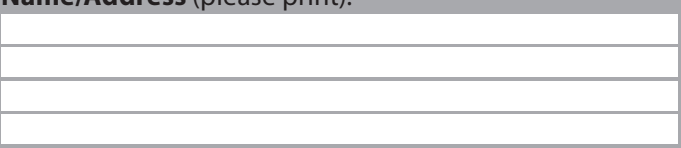

E-mail

\section{Date/Signature}

To be ordered through:

Prices subject to change, VAT not included

EUR price for eurozone countries, USD price for USA and Latin America only 